\title{
Use of PCR to detect mycoplasma DNA in respiratory tract specimens from adult HIV-positive patients
}

\author{
R. CULTRERA, DAISY ROULLAND-DUSSOIX*, R. ROMANI $\dagger$ and C. CONTINI
}

Section of Infectious Diseases, Department of Clinical and Experimental Medicine, University of Ferrara, Via Fossato di Mortara 23, 1-44100 Ferrara, Italy, * Laboratoire des Mycoplasmes, Institut Pasteur, 25 rue du Dr Roux, 75724 Paris Cédex 15, Paris, France and tDepartment of Infectious and Tropical Diseases, 'La Sapienza' University, Piazza A. Moro, l-00161 Rome, Italy

\begin{abstract}
The polymerase chain reaction (PCR) was evaluated retrospectively for its ability to detect Ureaplasma urealyticum and Mycoplasma spp. in respiratory tract specimens obtained from adult patients with AIDS. Mycoplasma DNA was detected in specimens from 12 of 84 patients. Of the 107 specimens tested, 13 and seven positive PCR results were obtained with the genus- and species-specific oligonucleotide primers used, respectively, in two different steps. With the latter, one sample was positive for $U$. urealyticum plus $M$. hominis, another for $M$. fermentans plus $M$. salivarium, and five others were positive for $M$. salivarium. The unexpected detection of $U$. urealyticum DNA in respiratory secretions from an adult AIDS patient suggested that this urogenital mycoplasma could have a role in determining or exacerbating respiratory tract infections in the HIV-positive population, but that its low rate of isolation could be related to the frequent failure of methods used currently to detect mycoplasmas.
\end{abstract}

\section{Introduction}

Ureaplasma urealyticum is a main cause of nonchlamydial, non-gonococcal urethritis and acute prostatitis, and can cause chorioamnionitis with pre-term delivery in pregnancy [1]. It also appears to be involved in respiratory disease of very low birth weight infants, and recent evidence indicates that $U$. urealyticum, alone or in addition to Mycoplasma hominis, is able to cause meningitis, particularly in the first few days of life in premature infants with respiratory disease or hydrocephalus [2]. U. urealyticum has also been isolated from immunosuppressed or hypogammaglobulinaemic patients with septic arthritis, but is isolated infrequently from respiratory specimens of children outside the neonatal period [3]. Moreover, evidence that $U$. urealyticum is involved in infections in AIDS patients is lacking.

Routine laboratory diagnosis is based mainly on serology and, to a lesser extent, on time-consuming cultivation techniques [4]. Considering the lack of

Received 8 Oct. 1997; revised version received 9 Feb. 1998; accepted 18 March 1998.

Corresponding author: Professor C. Contini. antibody production by immunosuppressed patients, the polymerase chain reaction (PCR) may represent a rapid, sensitive and specific tool to detect mycoplasmas in various biological fluids. This study investigated the use of PCR to detect DNA of $U$. urealyticum and Mycoplasma spp. in respiratory secretions from adult HIV-infected patients to assess the frequency of isolation and the clinical settings in which mycoplasmas were identified.

\section{Materials and methods}

\section{Specimen collection}

In total, 130 respiratory tract specimens, obtained by bronchoalveolar lavage (BAL) or from induced sputum (IS) or nasopharyngeal aspirates (NPA), were collected and frozen between March 1991 and April 1996 from 84 HIV-positive patients (54 males, 30 females; age range $24 \mathrm{SD} 7.1$ years; $\mathrm{CD} 4+$ cell counts $52 \mathrm{SD}$ $2.1 / \mathrm{mm}^{3}$ ) attending the Section of Infectious Diseases of the Department of Clinical and Experimental Medicine, University of Ferrara, and the Department of Infectious and Tropical Diseases of University ' $\mathrm{La}$ Sapienza' of Rome. The patients presented with radiographic abnormalities and mild respiratory symptomatology in the absence of concomitant pulmonary 
opportunist pathogens, including Pneumocystis carinii, Toxoplasma gondii and mycobacteria. In addition, 15 HIV-negative patients, chosen randomly from people who demanded HIV testing spontaneously in our institutions, were included in the study. This control group consisted of patients with negative serological tests for mycoplasmas, but from whom four BAL or IS specimens were positive for Mycoplasma spp. by routine culture examination at the time of sampling.

\section{Sample processing}

BAL was performed according to Hartman et al. [5]. For IS and NPA specimens, the method of Hague et al. [6] was used. Such specimens (c. 5-10 ml) were liquefied with Sputasol ${ }^{\mathrm{TM}}$ (Unipath) and then vortex mixed with glass beads for $3 \mathrm{~min}$. An equal volume of phosphate-buffered saline (PBS, pH 7.2) was added and samples were centrifuged at $2000 \mathrm{~g}$ for $15 \mathrm{~min}$. The pellet was resuspended in $1 \mathrm{ml}$ of PBS and stored until required for PCR evaluation. Sample lysis was by the method of Kellog and Kwok [7]. Briefly, $100 \mu \mathrm{l}$ of each sample were centrifuged at $10000 \mathrm{~g}$ for $15 \mathrm{~min}$ at $4^{\circ} \mathrm{C}$, the pellets resuspended in washing buffer $(10 \mathrm{mM}$ Tris- $\mathrm{HCl}, 50 \mathrm{mM} \mathrm{KCl}, 1.5 \mathrm{mM} \mathrm{MgCl}_{2}$ ), and then recentrifuged as above. Pellets were lysed in $25 \mu \mathrm{l}$ of solution A $(10 \mathrm{mM}$ Tris- $\mathrm{HCl}, \mathrm{pH} 8.3,100 \mathrm{mM} \mathrm{KCl}$, $\left.2.5 \mathrm{mM} \mathrm{MgCl}_{2}\right)$ and $25 \mu$ l of solution B (10 mM Tris$\mathrm{HCl}, \mathrm{pH} 8.3,2.5 \mathrm{mM} \mathrm{MgCl}_{2}$, Tween $201 \% \mathrm{v} / \mathrm{v}$, Triton $\mathrm{X}-1001 \% \mathrm{v} / \mathrm{v}$ ) containing proteinase $\mathrm{K} 120 \mu \mathrm{g} / \mathrm{ml}$. After incubation for $1 \mathrm{~h}$ at $60^{\circ} \mathrm{C}$, samples were heated at $95^{\circ} \mathrm{C}$ for $10 \mathrm{~min}$ in a water-bath and then cooled to room temperature.

\section{PCR conditions}

Standard precautions (keeping autoclaved reagents in small, single use volumes, UV irradiation treatment for surface laboratory benches, filter-tips, adding DNA last) were used to avoid the risk of contamination by DNA or PCR product carryover [8].

Initially, $2-\mu 1$ portions of undiluted and 10-fold dilutions of each sample were amplified with human globin-specific primers (GLO5/GLO6, 989 bp; Table 2) to test whether lysis had occurred [9]. Plasmid pBR322 DNA (Promega, Madison, WI, USA) was added to each sample, and PCR was performed with primers $\mathrm{pBR} 1 / \mathrm{pBR} 2$ (719 bp; Table 2) to identify any inhibition of amplification caused by the presence of inhibitors in the sample [10]. Mycoplasmas have been detected previously with genus-specific primers

Table 1. Sequences of primers used to amplify DNA from samples

\begin{tabular}{llc}
\hline Designation & Sequence 5' $^{\prime}$ - $^{\prime}$ & Reference \\
\hline GLO5 & TGGTAGCTGGATTGTAGCTG & {$[9]$} \\
GLO6 & ATTTTCCCACCCTTAGGCTG & {$[9]$} \\
PBR1 & CATCTCGGGCAGCGTTGGGT & {$[10]$} \\
PBR2 & ACAAGCTGTGACCGTCTCCG & {$[10]$} \\
PBR6 & AGCGCAGCGAGTCAGTGAGC & {$[10]$} \\
MGSO & TGCACCATCTGTCACTCTGTTAACCTC & {$[11]$} \\
GPO1 & ACTCCTACGGGAGGCAGCAGTA & {$[11]$} \\
UNI ${ }^{-}$ & TAATCCTGTTTGCTCCCCAC & {$[10]$} \\
RNA5 & AGAGTTTGATCCTGGCTCAGGA & {$[10]$} \\
PNEU-GEN & CCTGCAAGGGTTCGTTATTT & {$[10]$} \\
HOM+ & TGAAAGGCGCTGTAAGGCGC & {$[11]$} \\
SAL & GCTGCGTCAACAGTTCTCTG & {$[10]$} \\
PIR & GTCCGTTTGACCGCTATAG & {$[10]$} \\
ORA5 & GGAGCGTTTCGTCCGCTAAG & {$[10]$} \\
FER & AAGAAGCGTTTCTTCGCTGG & {$[10]$} \\
PEN2 & CAATCCTGATACATCCCGTA & Unpublished data \\
UU3 & GATGGTAAGTTAGTTGCTGAC & {$[12]$} \\
UU4 & ACGACGTCCATAAGCAACT & {$[12]$} \\
UU5 & CAATCTGCTCGTGAAGTATTAC & {$[13]$} \\
\hline
\end{tabular}

Table 2. Targets of primers used in PCR amplifications

\begin{tabular}{|c|c|c|c|}
\hline Target & $\begin{array}{l}\text { Primer } 1 \\
\text { (sense) }\end{array}$ & $\begin{array}{c}\text { Primer } 2 \\
\text { (antisense) }\end{array}$ & $\begin{array}{l}\text { Amplicon length } \\
\text { (bp) }\end{array}$ \\
\hline$\beta$-Globin gene & GLO5 & GLO6 & 989 \\
\hline Plasmid pBR322 DNA & PBR1 & PBR2 & 719 \\
\hline Plasmid pBR322 DNA & PBR1 & PBR6 & 974 \\
\hline Mycoplasmas & GPO1 & MGSO & 717 \\
\hline$M$. pneumoniae $+M$. genitalium & PNEU-GEN & MGSO & 851 \\
\hline M. fermentans & FER & $\mathrm{UNI}^{-}$ & 579 \\
\hline M. pirum & PIR & $\mathrm{UNI}^{-}$ & 579 \\
\hline M. salivarium & RNA5 & SAL & 839 \\
\hline M. hominis & HOM+ & $\mathrm{UNI}^{-}$ & 589 \\
\hline M. penetrans & RNA5 & PEN2 & 850 \\
\hline M. orale & ORA & $\mathrm{UNI}^{-}$ & 583 \\
\hline U. urealyticum & U3 & U4 & 456 \\
\hline U. urealyticum & U5 & $\mathrm{U} 4$ & 429 \\
\hline
\end{tabular}


(MGSO/GPO1, 717 bp; Table 2), followed by amplification of positive samples with species-specific primers for $M$. pneumoniae, $M$. genitalium, $M$. hominis, $M$. salivarium, $M$. orale, $M$. pirum, $M$. fermentans, $M$. penetrans and $U$. urealyticum (Table 2). Mycoplasma genus- and species-specific oligonucleotide primers (Unité de Chimie Organique, Institut Pasteur, Paris, France) were deduced mostly from either the conserved or variable $16 \mathrm{~S}$ RNA regions; $U$. urealyticum primers UU3, UU4 and UU5 were obtained from the urease gene sequence (Tables 1 and 2) [10-13]. M. penetrans primer PEN2 was chosen from the V5 variable region of the 16S rRNA gene after multiple alignment of several human mycoplasmas. The specificity of this primer was tested and it was found not to cross-react with human mycoplasmas other than $M$. penetrans (data not shown). PCR mixtures $(50 \mu \mathrm{l})$ contained $50 \mathrm{mM} \mathrm{KCl}$, $10 \mathrm{~mm}$ Tris- $\mathrm{HCl}, \mathrm{pH} 8.3,1.5 \mathrm{mM} \mathrm{MgCl}_{2}, 25 \mu \mathrm{M}$ tetramethylammonium chloride (Aldrich, Milwaukee, WI, USA), $40 \mathrm{pmol}$ of each primer, $0.2 \mathrm{mM}$ dNTPs and $1 \mathrm{U}$ of Taq DNA polymerase (Promega) and were overlaid with two drops of mineral oil. DNA sample $(2 \mu 1)$ was added through the oil. PCR conditions comprised initial denaturation for $15 \mathrm{~min}$ at $95^{\circ} \mathrm{C}$, followed by 30 cycles of $30 \mathrm{~s}$ at $95^{\circ} \mathrm{C}, 90 \mathrm{~s}$ at $58^{\circ} \mathrm{C}$, and $90 \mathrm{~s}$ (increased $1 \mathrm{~s} /$ cycle) at $72^{\circ} \mathrm{C}$, with final extension period at $72^{\circ} \mathrm{C}$ for $10 \mathrm{~min}$ [10].

\section{Analysis of amplified DNA}

Portions $(20 \mu 1)$ of amplified products were electrophoresed in agarose $0.8 \% \mathrm{w} / \mathrm{v}$ gels in TAE buffer (40 mM Tris-acetate, $1 \mathrm{~mm}$ EDTA, pH 8), together with positive and negative controls, and DNA bands were visualised under UV illumination after ethidium bromide staining.

\section{Results and discussion}

\section{Sensitivity of the PCR assay}

$M$. pneumoniae strain $\mathrm{FH}$ was grown and harvested in late exponential phase and DNA was extracted and purified as described previously [10]. Serial 10-fold DNA dilutions were used for amplification with the genus-specific primers MGSO/GPO1. Visible PCR products $(717 \mathrm{bp})$ could be detected on stained agarose gels at a dilution representing $\leqslant 10 \mathrm{fg}$, which corresponded to $c .10$ mycoplasmas $/ \mathrm{ml}$. This procedure was followed for all the mycoplasmas mentioned above and the results indicated that 5-15 micro-organisms could be detected, depending on the species tested.

\section{Detection of mycoplasmas in respiratory secretions}

Of the total specimens amplified, 23 failed to yield a PCR product from the pBR322 control DNA at two. dilutions. These specimens were not used in the analysis for mycoplasma DNA by PCR, which was thus performed on the remaining 107 specimens. Of these, 13 were positive for mycoplasma DNA, either with genus-specific $(\mathrm{n}=13)$ or with species-specific $(n=7)$ primers in 12 and six AIDS patients, respectively (Table 3 ). One specimen contained both $U$. urealyticum and $M$. hominis DNA after amplification with UU3/UU4 primers (456-bp DNA band) followed by another amplification with UU4/UU5 primers (429-bp DNA band). Another specimen contained $M$. salivarium DNA plus $M$. fermentans DNA, while five other samples were also PCR-positive for $M$. salivarium DNA. All samples from HIV-negative patients which were positive by culture for Mycoplas$m a$ were also positive for $M$. salivarium DNA by PCR.

Table 3. Detection of mycoplasma DNA by PCR in respiratory secretions of HIV-infected patients

\begin{tabular}{|c|c|c|c|c|c|c|c|c|c|c|c|}
\hline \multirow{2}{*}{$\begin{array}{l}\text { Patient } \\
\text { no. }\end{array}$} & \multirow[b]{2}{*}{ Clinical data } & \multicolumn{2}{|c|}{$\begin{array}{l}\text { DNA detection } \\
\text { (positive samples/ } \\
\text { total samples) }\end{array}$} & \multicolumn{8}{|c|}{ Mycoplasma DNA amplification } \\
\hline & & genus & species & sal & ora & hom & pneu/gen & pen & ferm & pir & $U u$ \\
\hline 1 & $\begin{array}{l}\text { AIDS, past PCP, atypical bronchovascular } \\
\text { markings }\end{array}$ & $1 / 3$ & $1 / 3$ & + & - & - & - & - & + & - & - \\
\hline 2 & AIDS, past PCP, endocarditis, & $1 / 3$ & $1 / 3$ & + & - & + & - & - & - & - & - \\
\hline 3 & AIDS & $1 / 2$ & $0 / 2$ & - & - & - & - & - & - & - & - \\
\hline 4 & $\begin{array}{l}\text { Advanced AIDS, past PCP, bronchovascular } \\
\text { markings, lung infiltrates }\end{array}$ & $2 / 3$ & $2 / 3$ & $+(2)$ & - & - & - & - & - & - & - \\
\hline 5 & AIDS, past TBC, bronchovascular infiltrates & $1 / 1$ & $1 / 1$ & + & - & - & - & - & - & t & - \\
\hline 6 & AIDS, CMV retinitis, disseminated TBC & $1 / 1$ & $0 / 1$ & - & - & - & - & - & - & - & - \\
\hline 7 & AIDS, past TBC, cough, interstitial infiltrates & $1 / 1$ & $1 / 1$ & - & - & + & - & - & - & - & + \\
\hline 8 & AIDS, KS & $1 / 1$ & $0 / 1$ & - & - & - & - & - & - & - & - \\
\hline 9 & ARC, pneumonia & $1 / 1$ & $0 / 1$ & - & - & - & - & - & - & - & - \\
\hline 10 & ARC, hepatitis & $1 / 1$ & $0 / 1$ & - & - & - & - & - & - & - & $\ldots$ \\
\hline 11 & AIDS, bronchovascular infiltrates & $1 / 1$ & $1 / 1$ & + & - & + & - & - & - & - & - \\
\hline 12 & $\begin{array}{l}\text { AIDS, cerebral lymphoma, CMV retinitis, } \\
\text { lung nodular infiltrates }\end{array}$ & $1 / 1$ & $0 / 1$ & - & - & - & - & - & - & - & $\ldots$ \\
\hline
\end{tabular}

sal, M. salivarium; ora, $M$. orale; hom, M. hominis; pneu/gen, M. pneumoniae and $M$. genitalium; pen, M. penetrans; ferm, M. fermentans; pir, M. pirum; Uu, U. urealyticum; PCP, Pneumocystis carinii pneumonia; TBC, Mycobacterium tuberculosis infection. 
BAL samples from HIV-infected patients are contaminated frequently by upper respiratory tract and oral flora, including mycoplasmas, for which the frequency of isolation is higher than that from HIVnegative patients [14]. The present study raises the question of the possible role of $U$. urealyticum in triggering pulmonary disease in HIV-infected patients. To date, this organism has been implicated, in addition to urogenital tract infections, in causing bronchospasm and chronic lung diseases in infants and young children [15]. In the present report, $U$. urealyticum DNA was detected in lung secretions from an adult patient with AIDS who presented with cough and chest signs of bronchovascular markings in the absence of severe respiratory disease. The low rate of isolation may not be representative of the frequency with which $U$. urealyticum is involved in the causation of lung injury, and the possibility that this mycoplasma could be involved as a pathogen in respiratory tract infections or self-limiting interstitial pneumonia cannot be excluded. Furthermore, it is unclear whether it is found alone or in combination. M. hominis is habitually associated with genitourinary tract infections, pelvic inflammatory disease, and post-abortion fever. The unusual association of $U$. urealyticum with $M$. hominis observed in the present study could contribute to, cause, or worsen lung disease in the HIV-infected population.

This work was supported by grants of MURST-60\%, 1996 and 1997 and Fondazione CARIFE for special projects. We thank A. Henry and B. Lemercier for excellent technical support and C. Prevost for skilled laboratory assistance.

\section{References}

1. Baum SG, Taylor-Robinson D. Mycoplasma diseases. In: Mandell GL, Bennett JE, Dobin R (eds) Mandell, Douglas and Bennett's Principles and practice of infectious diseases, 4th edn. New York, Churchill Livingstone. 1995: 1701-1718.

2. Heggie AD, Jacobs MR, Butler VT, Baley JE, Boxerbaum B. Frequency and significance of isolation of Ureaplasma urealyticum and Mycoplasma hominis from cerebrospinal fluid and tracheal aspirate specimens from low birth weight infants. $J$ Pediatr 1994; 124: 956-961.

3. Taylor-Robinson D, Furr PM, Webster F, Webster ADB. Ureaplasma urealyticum in the immunocompromised host. Pediatr Infect Dis 1986; 5 (Suppl 6): S236-S238.

4. Skakni L, Sardet L, Just J et al. Detection of Mycoplasma pneumoniae in clinical samples from pediatric patients by polymerase chain reaction. J Clin Microbiol 1992; 30: 2638-2643.

5. Hartman B, Koss M, Hui A, Baumann W, Athos L, Boylen T. Pneumocystis carinii pneumonia in the acquired immunodeficiency syndrome (AIDS). Diagnosis with bronchial brushings, biopsy, and bronchoalveolar lavage. Chest 1985; 87: 603-607.

6. Hague RA, Burns SE, Mok JYQ, Yap PL. Diagnosis of Pneumocystis carinii pneumonia from non-invasive sampling of respiratory secretions. Arch Dis Child 1990; 65: 1364-1365.

7. Kellog DE, Kwok S. Detection of human immunodeficiency virus. In: Innis MA, Gelfand DH, Sninsky JJ, White TJ (eds) PCR protocols: a guide to methods and applications. San Diego, Academic Press. 1990: 337-347.

8. Kwok S, Higuchi R. Avoiding false positives with PCR. Nature 1989; 339: 237-238.

9. Saiki RK, Gelfand DH, Stoffel $\mathrm{S}$ et al. Primer-directed enzymatic amplification of DNA with a thermostable DNA polymerase. Science 1988; 239: 487-491.

10. Roulland-Dussoix D, Henry A, Lemercier B. Detection of mycoplasmas in cell cultures by PCR: a one year study. J Microbiol Methods 1994; 19: 127-134.

11. van Kuppeveld FJM, van der Logt JTM, Angulo AF et al. Genus- and species-specific identification of Mycoplasmas by 16S rRNA amplification. Appl Environ Microbiol 1992; 58: 2606-2615.

12. Blanchard A. Ureaplasma urealyticum urease genes; use of a UGA tryptophan codon. Mol Microbiol 1990; 4: 669-676.

13. Blanchard A, Hentschel J, Duffy L, Baldus K, Cassell GH. Detection of Ureaplasma urealyticum by polymerase chain reaction in the urogenital tract of adults, in amniotic fluid, and in the respiratory tract of newborns. Clin Infect Dis 1993; 17 Suppl 1: S148-153.

14. Teel LD, Finelli MR, Johnson SC. Isolation of Mycoplasma species from bronchoalveolar lavages of patients positive and negative for human immunodeficiency virus. J Clin Microbiol 1994; 32: 1387-1389.

15. Cassell GH, Waites KB, Crouse DT et al. Association of Ureaplasma urealyticum infection of the lower respiratory tract with chronic lung disease and death in very-low-birth-weight infants. Lancet 1988; 2: 240-244. 